\title{
[Regular Paper] \\ Viscosity Properties and Molecular Structure of Lube Base Oil Prepared from Fischer-Tropsch Waxes
}

\author{
Manabu KoBAYASHI*, Masayuki SAITOH, Katsuaki IsHIDA, and Hiroshi YACHI \\ Petroleum Refining Research \& Technology Center, Japan Energy Corp., 3-17-35 Niizo-Minami, Toda, Saitama 335-8502, JAPAN
}

(Received March 29, 2005)

\begin{abstract}
Lube base oils were prepared by hydrocracking/isomerization of Fischer-Tropsch synthesized waxes and longchain $\alpha$-olefins with various carbon chain lengths. Correlations between operation conditions, viscosity properties of base oil, and molecular structures were investigated. Prepared base oils showed very high viscosity indexes of up to 159 , but these varied widely with the severity of the hydrocracking/isomerization conditions and feedstock. Viscosity indexes of base oil had a good correlation with the severity of the hydrocracking/isomerization conditions, that is higher conversion resulted in lower viscosity index. "Average branching numbers" were calculated from the average carbon numbers and the ratio of $\mathrm{CH}, \mathrm{CH}_{3}$ carbons obtained from ${ }^{13} \mathrm{C}-\mathrm{NMR}$ analysis, considering that the base oils mainly consisted of noncyclic paraffins. Increased conversion resulted in decreased average carbon number and increased average branching number with all feedstocks. Even with conversion of under $10 \%$, about 2 branches per molecule were generated. On the other hand, the rate of generation of 3 or more branches was comparatively low. Average carbon number and average branching number also showed good correlations with the viscosity properties of the base oil such as kinematic viscosity and viscosity index. Viscosity indexes increased with higher average carbon number or lower average branching number. The effect of average carbon number or average branching number on the viscosity index depended on the feedstock, so a new index (average carbon number $)^{2} \times(\text { average branching number })^{-1}$ was introduced as a molecular structural parameter of paraffins, and the index was confirmed to indicate the viscosity index regardless of the feedstock. A similar structural parameter (average carbon number) ${ }^{a} \times\left(\right.$ average branching number) ${ }^{b}$ was applied to kinematic viscosity. Kinematic viscosities at $40^{\circ} \mathrm{C}$ and $100^{\circ} \mathrm{C}$ showed good correlations when $(a, b)=(3.5$, $0.9)$ and $(3.0,0.5)$, respectively.
\end{abstract}

\section{Keywords}

Fischer-Tropsch wax, $\alpha$-Olefin, Isomerization, Lubricant base oil, Viscosity index, Average branching number

\section{Introduction}

The increasing interests in environmental issues have boosted the demand for high efficiency clean fuel, that is, sulfur-free diesel oil or gasoline. This recent tendency has also required improvement in the properties of lubricant oil cleaner and more efficient as well. According to a recent survey ${ }^{1)}$, the total demand for lube base oil has been almost constant during the past two decades, but the demand for high grade base oil (i.e. Group II or III) has gradually increased. Base oils prepared from paraffinic and clean source, such as Fischer-Tropsch (FT) synthesized paraffin, are becoming more attractive as these products mainly consist of noncyclic paraffins and have very high viscosity index$\mathrm{es}^{2}$. The Gas-to-Liquid project is now being developed all over the world ${ }^{3), 4)}$ and high performance lube

\footnotetext{
* To whom correspondence should be addressed.

* E-mail: ma.kobay@j-energy.co.jp
}

base oil is expected to be a product from FT wax as well as clean fuel oil.

One of the most fundamental structural parameters of base oil is the carbon number distribution, but this parameter is too complicated to relate to the performance of base oil, so the average carbon number was taken as the parameter that represents the size of molecule. Another important structural parameter is the branching of the paraffin molecule. Base oil contains so many isomers that it is impossible to identify all isomers, for example by chromatography. One effective way to measure the branching of base oil is to investigate the $\mathrm{CH}_{3}$ carbon or $\mathrm{CH}$ carbon ratio using ${ }^{13} \mathrm{C}-\mathrm{NMR}$ (nuclear magnetic resonance). Assuming that there is no quaternary carbon atom, the peaks of ${ }^{13} \mathrm{C}$-NMR can be assigned to $\mathrm{CH}, \mathrm{CH}_{2}$, or $\mathrm{CH}_{3}$ carbon. Considering that base oil consists mainly of noncyclic paraffins, the average branching number can be calculated using the ratio of $\mathrm{CH}$ or $\mathrm{CH}_{3}$ with average carbon number. 
Table 1 Properties of Feedstock

\begin{tabular}{|c|c|c|c|c|c|}
\hline & & FTW-1 & FTW-2 & $\mathrm{AO}-1$ & AO-2 \\
\hline Density $/ 15^{\circ} \mathrm{C}$ & {$\left[\mathrm{g} / \mathrm{cm}^{3}\right]$} & 0.809 & 0.817 & 0.825 & 0.848 \\
\hline Carbon number distributi & & $\mathrm{C} 18-35$ & $\mathrm{C} 19-54$ & $\mathrm{C} 20-36$ & C28-46 \\
\hline Iodide number & [g/100 g-oil] & N.A. & N.A. & 73.9 & 39.1 \\
\hline Number of unsaturations & {$[\mathrm{mol} / \mathrm{mol}]$} & N.A. & N.A. & 0.953 & 0.760 \\
\hline \multirow{5}{*}{$\begin{array}{l}\text { Distillation } \\
\text { properties }\left[{ }^{\circ} \mathrm{C}\right] \\
\text { (D 2887) }\end{array}$} & IBP & 316.0 & 343.0 & 336.5 & 430.0 \\
\hline & $10 \%$ & 379.0 & 401.0 & 343.5 & 449.0 \\
\hline & $50 \%$ & 416.5 & 474.0 & 368.5 & 494.5 \\
\hline & \multirow{2}{*}{$\begin{array}{c}90 \% \\
\mathrm{EP}\end{array}$} & 456.5 & 524.0 & 431.5 & 562.0 \\
\hline & & 488.5 & 580.5 & 521.0 & 610.0 \\
\hline
\end{tabular}

N.A. = not analyzed

The present study investigated the relationship between the hydrocracking/isomerization conditions, quality of base oil products, and molecular structures to design the base oil molecular structure and optimize the base oil production. Base oils were prepared from FT waxes and long chain $\alpha$-olefins under various hydrocracking/isomerization conditions. The products showed a wide range of viscosity indexes from 114 to 159 depending on operation conditions. We focused on relating these two structural parameters to the operation conditions and viscosity properties of the base oil.

\section{Experimental}

\section{1. Hydrocracking / Isomerization of Feedstock}

FT waxes and long chain $\alpha$-olefins were used as feedstock for the preparation of lube base oils. The carbon number distribution and other properties are shown in Table 1. Commercial isomerization catalyst HOP-302 $(100 \mathrm{~m} l)$ developed by Japan Energy Corp. was filled in a fixed bed flow reactor with $\alpha$-alumina $(100 \mathrm{ml})$ as diluent. The hydrocracking/isomerization conditions were as follows: $\mathrm{H}_{2}$ pressure 4.0-9.0 $\mathrm{MPa}, \mathrm{H}_{2} /$ oil ratio $660-1500 \mathrm{~N} / / l$, operation temperature $340-370^{\circ} \mathrm{C}$, liquid hourly space velocity, LHSV 0.33 $1.00 \mathrm{~h}^{-1}$. Before providing feedstock, catalysts were sulfided with gas oil solution containing 1 vol\% carbon disulfide. Liquid samples were obtained after oil/gas separation.

\section{2. Analysis of Base Oils}

Distillation properties of product oils were evaluated with the ASTM D 2887 method to determine $360^{\circ} \mathrm{C}^{+}$ conversion defined as Eq. (1).

$360^{\circ} \mathrm{C}^{+}$conversion $(\mathrm{wt} \%)=$

$$
\left(\mathrm{C}_{0}-\mathrm{C}_{1}\right) / \mathrm{C}_{0} \times 100
$$

where $\mathrm{C}_{0}(\mathrm{wt} \%)=360^{\circ} \mathrm{C}^{+}$fraction of feedstock (2)

$$
\mathrm{C}_{1}(\mathrm{wt} \%)=360^{\circ} \mathrm{C}^{+} \text {fraction of products (3) }
$$

Except when the $n$-paraffin content was under $1 \mathrm{wt} \%$, product oils were dewaxed with mixed solvent (50\% 2butanone $/ 50 \%$ toluene). Dewaxed samples were distilled with a TBP distillation apparatus and the bottom oils with boiling point above $360^{\circ} \mathrm{C}$ were taken as the

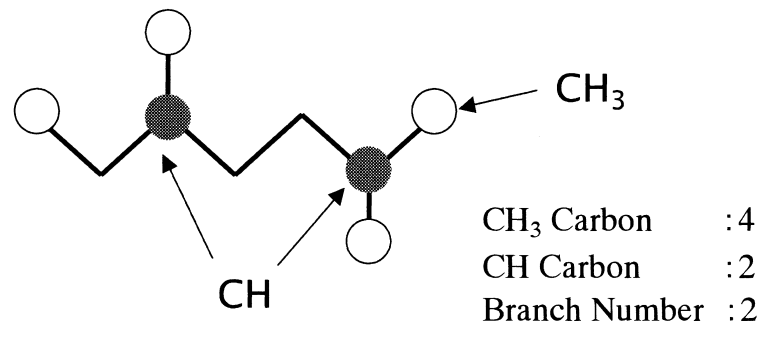

Fig. 1 Structure of 2 Branched Isoparaffin: Relationship of $\mathrm{CH}_{3}, \mathrm{CH}$ Carbon Ratio and Branching Number

lube base oil samples.

Kinematic viscosities at $37.8,40,98.9$ and $100^{\circ} \mathrm{C}$ were analyzed with the ASTM D 445 method. The Distortionless Enhancement by Polarization Transfer (DEPT) method was used to assign each peak of the ${ }^{13} \mathrm{C}$-NMR analysis of base oils to $\mathrm{CH}, \mathrm{CH}_{2}$, and $\mathrm{CH}_{3}$ carbon assuming that quaternary carbon atoms were not present. Analysis was performed with a JEOL Ltd. GSX-270 NMR spectrometer with a $10 \mathrm{~mm}$ sample tube filled with approximately $50 \%$ of sample oil diluted with $\mathrm{CDCl}_{3}$. Each peak was quantified by the analysis of ${ }^{1} \mathrm{H}$ gated decoupling without NOE, because the peak area obtained by the DEPT method is not quantitative.

\section{3. Determination of the Structural Parameters of Isoparaffins}

Average Carbon Numbers (ACNs): Average molecular weights were calculated from the kinematic viscosities at $37.8^{\circ} \mathrm{C}$ and $98.9^{\circ} \mathrm{C}$ by the ASTM D 2502-92 method. ACNs were calculated with Eq. (4), assuming that base oil samples in this study virtually consisted of only noncyclic paraffins with molecular formula of $\mathrm{C}_{n} \mathrm{H}_{2 n+2}$.

$\mathrm{ACN}=($ average molecular weight -2$) / 14$

Average Branching Numbers (ABNs): The ABNs, were calculated with two methods. As shown in Fig. $\mathbf{1}, \mathrm{ABN}$ is equal to the average number of $\mathrm{CH}_{3}$ carbons in one molecule minus 2 (Method A). ABNs can also be derived by counting $\mathrm{CH}$ carbon number in one molecule (Method B). Both $\mathrm{CH}_{3}$ and $\mathrm{CH}$ carbon ratios were obtained from ${ }^{13} \mathrm{C}-\mathrm{NMR}$ analysis. $\mathrm{ABNs}$ 
were calculated with the two methods and compared.

Method $\mathrm{A}: \mathrm{ABN}=\mathrm{ACN} \times \mathrm{CH}_{3}$ carbon ratio -2

Method $\mathrm{B}: \mathrm{ABN}=\mathrm{ACN} \times \mathrm{CH}$ carbon ratio

\section{Results and Discussion}

\section{1. Properties of Prepared Base Oil}

Most prepared base oils have very high viscosity indexes from 130 up to 159 . However, one sample had a relatively lower viscosity index (113.8). These results suggest that it is important to optimize the operation conditions of the hydrocracking/isomerization reaction and to understand the molecular structure change during the preparation of high viscosity index lube base oils.

Analysis of FD-MS and iodine number confirmed that no olefins and a small amount of cyclic paraffins containing 1 naphthene ring were present in the prepared base oil. Figure 2 shows that at lower conversion under $40 \mathrm{wt} \%$, the ratio of paraffins containing naphthene rings were very low, though at higher conversion ratio the content was relatively higher. This suggests that paraffins containing naphthene rings were generated in the process of isomerization. ${ }^{13} \mathrm{C}-\mathrm{NMR}$ spectra (Fig. 3) or column chromatography indicated that the base oils did not contain aromatic compounds.

Based on these results, the molecular structures of base oils in this study were evaluated using 2 parameters of isoparaffin, a parameter that represents molecular size (carbon number), and the state of branching.

\section{2. Comparison of $A B N$ by Method $A$ and Method B}

ABNs obtained by method A and method B are compared in Fig 4. The good correlation suggests that the

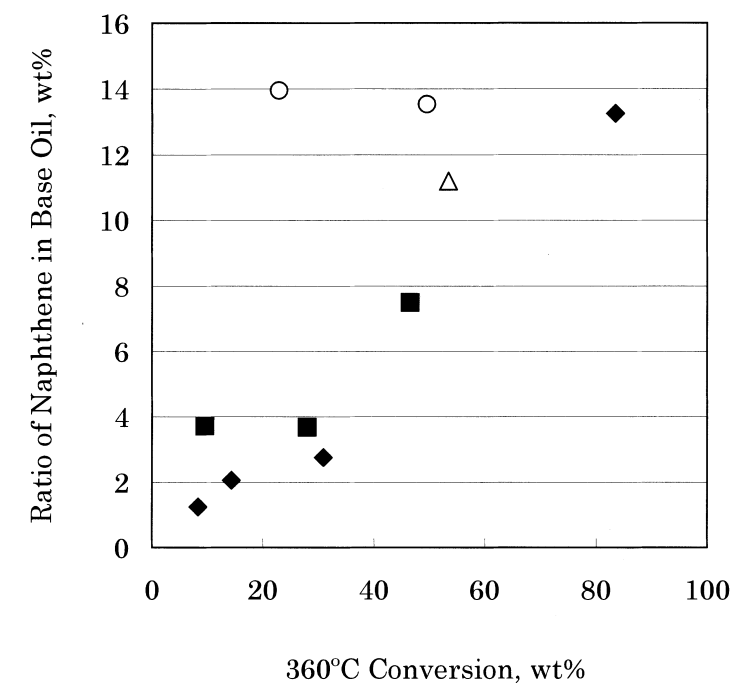

FTW-1, $\square$ FTW-2, $\triangle \mathrm{AO}-1, \bigcirc \mathrm{AO}-2$.

Fig. 2 Correlation between $360^{\circ} \mathrm{C}$ Conversion and Naphthene Content in Base Oil

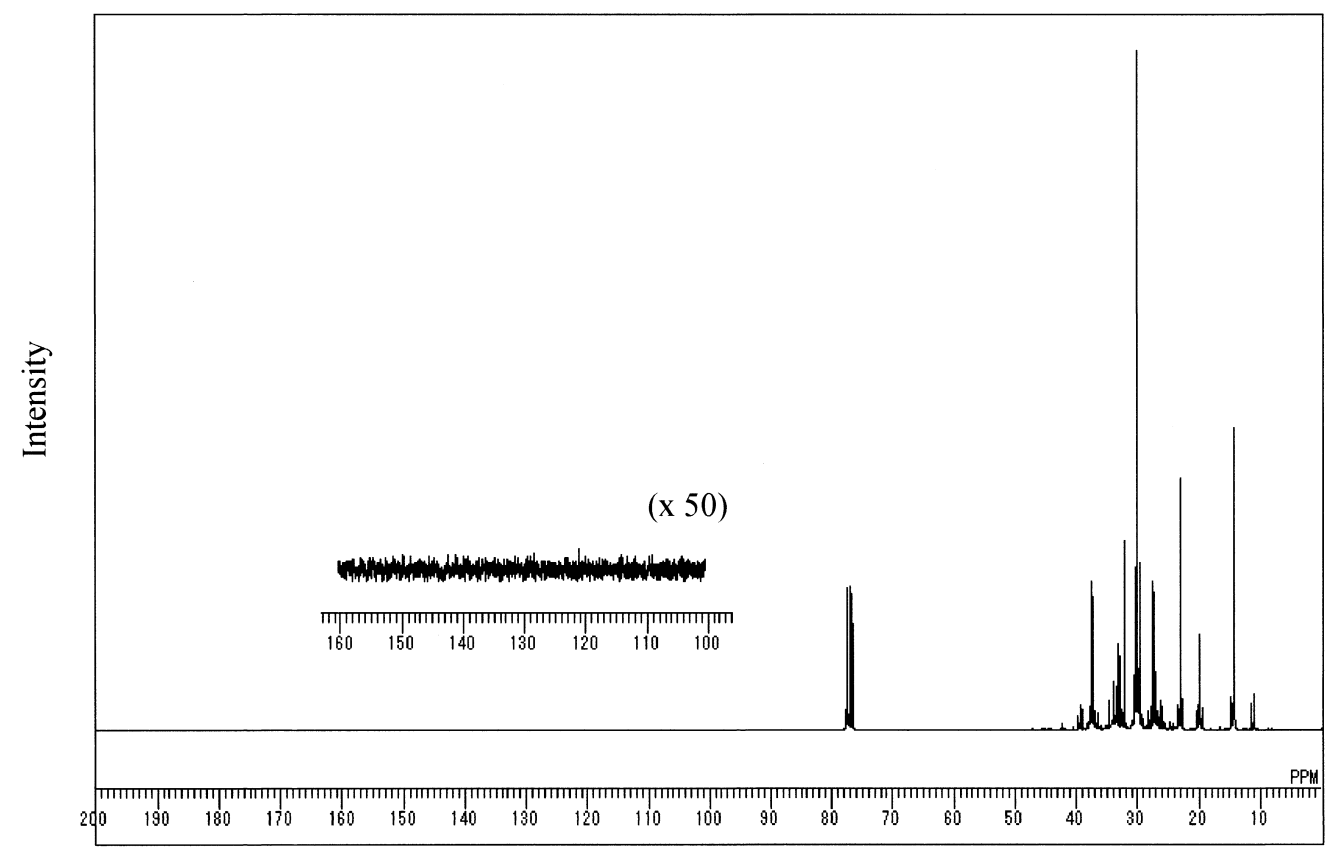

Chemical Shift, ppm

Feedstock: FTW-1, hydrocracking/isomerization conducted under the following conditions. $\mathrm{H}_{2}$ pressure: $9.0 \mathrm{MPa}, \mathrm{H}_{2} /$ oil ratio: $1500 \mathrm{~N} l / l$, operation temperature: $350^{\circ} \mathrm{C}$, LHSV: $0.44 \mathrm{~h}^{-1}$.

Fig. $3{ }^{13}$ C-NMR Spectrum of Lube Base Oil 


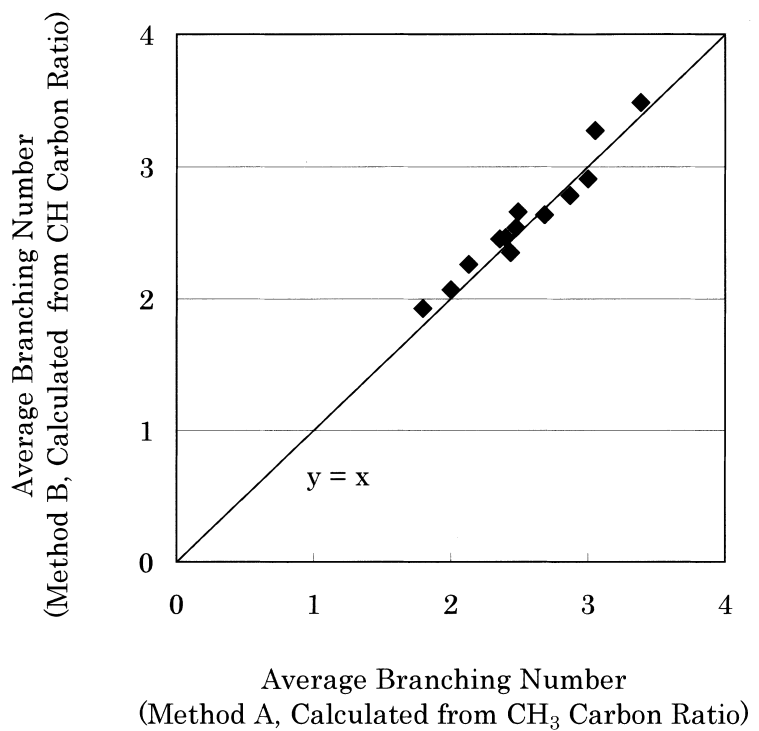

Fig. 4 Comparison of Average Branching Numbers Calculated from Method A and B

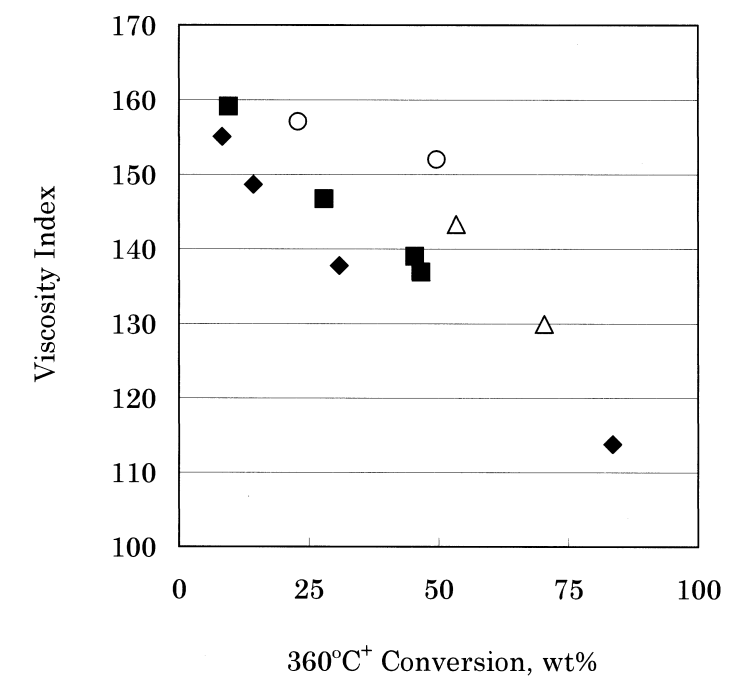

FTW-1, 口FTW-2, $\triangle$ AO-1, ○ AO-2.

Fig. 5 Correlation between $360^{\circ} \mathrm{C}^{+}$Conversion and Viscosity Index of Base Oil

calculation method proposed in this report using analytical data of ${ }^{13} \mathrm{C}-\mathrm{NMR}$ is reliable. ABNs obtained by these methods can be applied to the investigation of the molecular structure of isoparaffins in lube base oils. ABNs obtained of method A are the basis of the following discussion.

\section{3. Viscosity Index and Molecular Structure}

Figure 5 shows the effect of the severities of the hydrocracking/isomerization reaction on the viscosity index of base oil. The viscosity index was drastically lowered with increased conversion with every feedstock. These changes can be attributed to structural

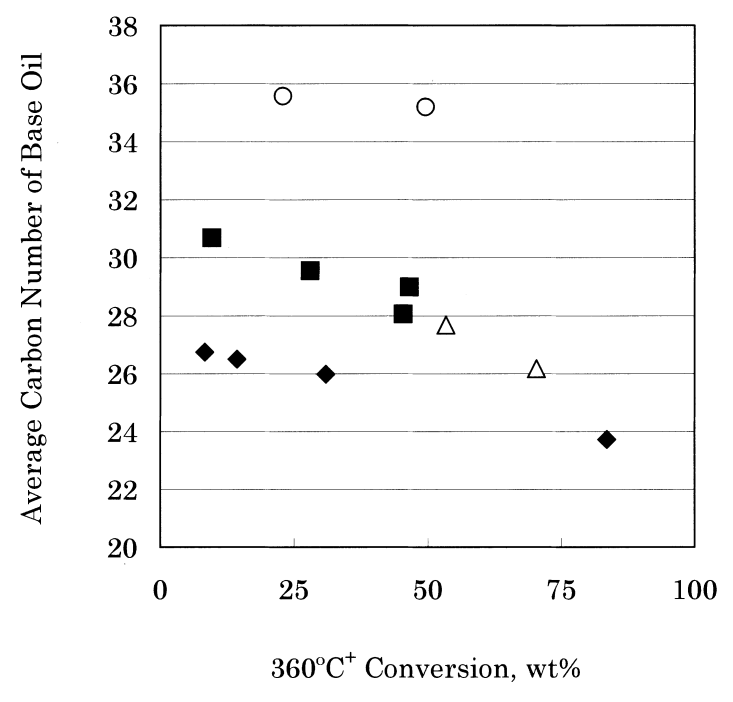

FTW-1, 口FTW-2, $\triangle$ AO-1, ○ AO-2.

Fig. 6 Correlation between $360^{\circ} \mathrm{C}^{+}$Conversion and Average Carbon Number of Base Oil

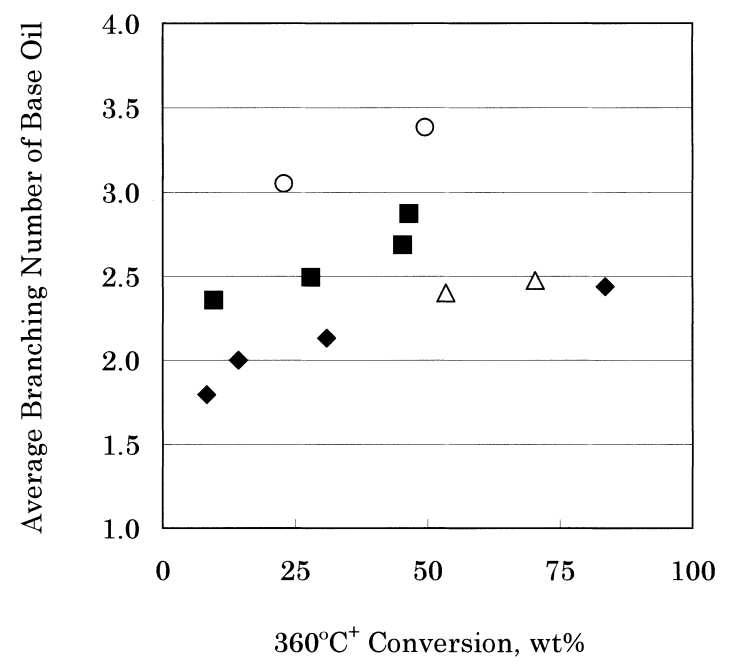

FTW-1, aFTW-2, $\triangle \mathrm{AO}-1, \bigcirc \mathrm{AO}-2$.

Fig. 7 Correlation between $360^{\circ} \mathrm{C}^{+}$Conversion and Average Branching Number of Base Oil

changes of the isoparaffins which form the base oils. $360^{\circ} \mathrm{C}^{+}$conversion was varied by changing both operation temperature and liquid hourly space velocity, LHSV. However, properties of base oils or molecular structure changes could be described as a function of only $360^{\circ} \mathrm{C}^{+}$conversion, that is $360^{\circ} \mathrm{C}^{+}$conversion is the only index that represents the severity of the hydrocracking/isomerization reaction.

Figures 6 and 7 show the correlation of $360^{\circ} \mathrm{C}^{+}$conversion with $\mathrm{ACN}$ and $\mathrm{ABN}$, respectively. In the case of FTW-1, even at very low conversion (below 10 wt\%), about 2 branches were generated (Fig. 7). 

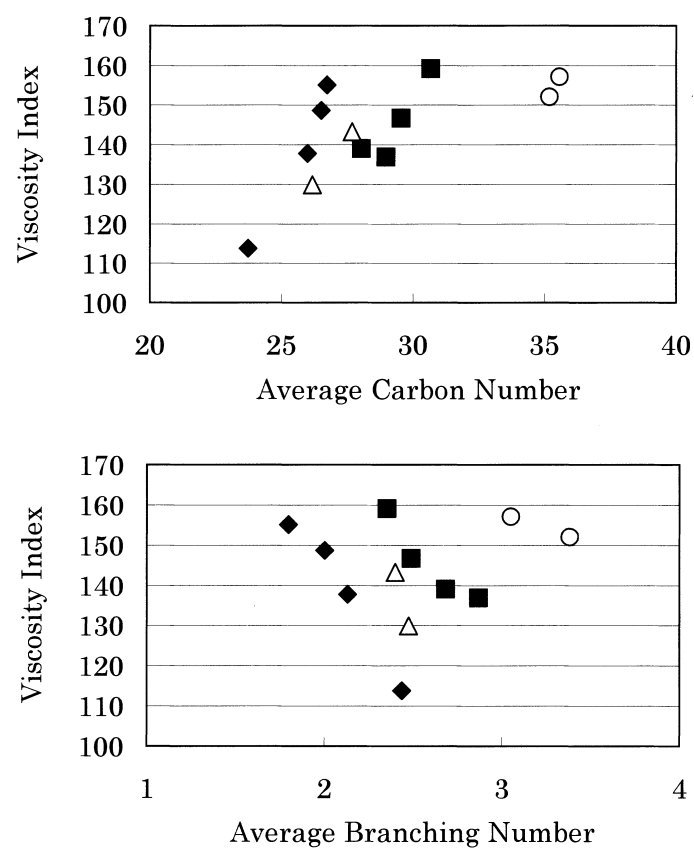

$\diamond$ FTW-1, $\mathbf{F T W}-2, \triangle \mathrm{AO}-1, \bigcirc \mathrm{AO}-2$.

Fig. 8 Correlation between Average Carbon Number, Average Branching Number and Viscosity Index of Base Oil

With increased conversion, $\mathrm{ABN}$ increased up to 2.4 and other feedstocks showed similar trends. These results show that the formation of the first and second branches in the paraffin chain is a very quick reaction. On the other hand, the formation of the third and subsequent branches is comparatively slow. ACN tended to decline with increased conversion of all feedstocks (Fig. 6). This result indicates that the base oils became lighter.

These findings suggest some kind of correlation of $\mathrm{ACN}$ and $\mathrm{ABN}$ with the viscosity indexes as shown in Fig. 8 and correlation curves depend on the feedstock. These results indicate that both $\mathrm{ACN}$ and $\mathrm{ABN}$ are important factors for the viscosity index. Therefore, we attempted to describe viscosity indexes as a function of $\mathrm{ACN}$ and $\mathrm{ABN}$ with following Eq. (7).

viscosity index $=f\left\{(\mathrm{ACN})^{a} \times(\mathrm{ABN})^{b}\right\}$

Using $(a, b)=(2,-1)$ as multipliers, Eq. (7) and viscosity index showed good correlation as a quadratic curve regardless of used feedstock as shown in Fig. 9. This result shows that viscosity indexes of base oils prepared by hydrocracking/isomerization of waxy feedstock can be determined as a function of $\mathrm{ACN}$ and $\mathrm{ABN}$. The obtained formula $(\mathrm{ACN})^{2} \times(\mathrm{ABN})^{-1}$ was factorized as shown in Eq. (8) to analyze the adopted multipliers. The viscosity index can be expressed by multiplication of a function that expresses the size of the molecule $(\mathrm{ACN})$ and a function that relates to the methylene chain length of the paraffin $\left.\left((\mathrm{ACN}) \times(\mathrm{ABN})^{-1}\right)\right)$.

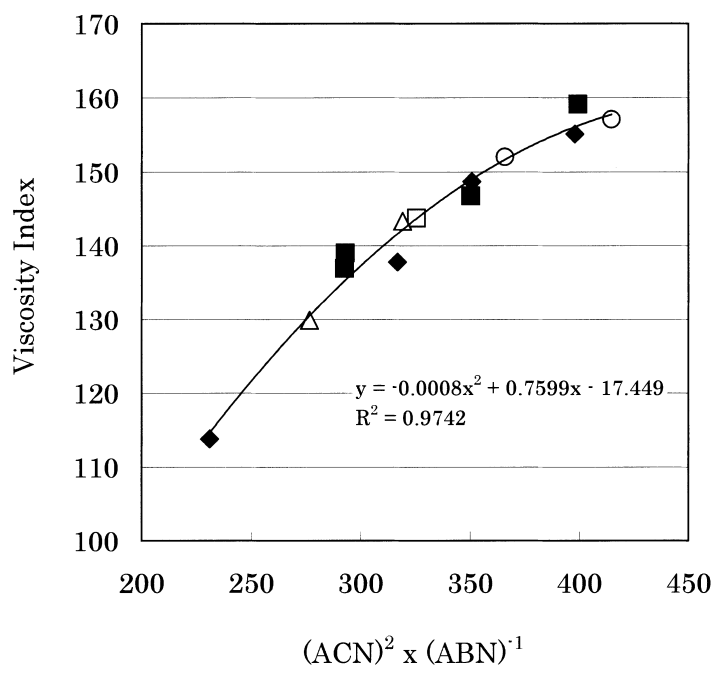

$(\mathrm{ACN})=$ average carbon number, $(\mathrm{ABN})=$ average branching number. FTW-1, $\square$ FTW-2, $\square$ FTW-2 ( $400^{\circ} \mathrm{C}$ cut $), \triangle \mathrm{AO}-1$, AO-2.

Fig. 9 Correlation between New Structural Parameter $(\mathrm{ACN})^{2} \times(\mathrm{ABN})^{-1}$ and Viscosity Index of Base Oil

$$
\begin{aligned}
&(\mathrm{ACN})^{2} \times(\mathrm{ABN})^{-1}= \\
&(\mathrm{ACN}) \times\left\{(\mathrm{ACN}) \times(\mathrm{ABN})^{-1}\right\}
\end{aligned}
$$

It may seem a little strange that the viscosity indexes could be represented only by $\mathrm{ACN}$ and $\mathrm{ABN}$, because the location of branches or the type of branches, such as methyl or ethyl or so on, strongly affect the viscosity properties of base oil ${ }^{5)}$. This result indicates that the location of branches or the type of branches have only a few variations in the case of hydrocracking/isomerization of Fischer-Tropsch paraffins or $\alpha$-olefins. Reference 5) shows some properties of various kinds of hydrocarbons, such as kinematic viscosity or viscosity index. It is difficult to compare directly these data with the present results as the structures of some isoparaffins found in this reference are not practical in the case of base oils prepared from FT wax hydrocracking/isomerization, but the values can be of great help for understanding the result of our study.

As our results indicated that methylene chain length of paraffin is supposed to be an important factor for viscosity index, the influence of methylene length was investigated. A new molecular structural parameter that we call Methylene Chain Index was employed for this investigation. Methylene Chain Index $=\Sigma\left(M L^{1.5}\right)$ where $M L=$ methylene length. For example, the molecule shown in Fig. $\mathbf{1 0}$ has 4 carbon, 5 carbon, and 6 carbon methylene chains, so $\Sigma\left(M L^{1.5}\right)=4^{1.5}+5^{1.5}+6^{1.5}=$ 33.9. Figure $\mathbf{1 0}$ shows the correlation of Methylene Chain Index of several $i$-C26s and $n$-C26 with viscosity index, and indicates that longer methylene length is favorable for higher viscosity index. The influence of carbon number is also confirmed in Fig. 11. This 

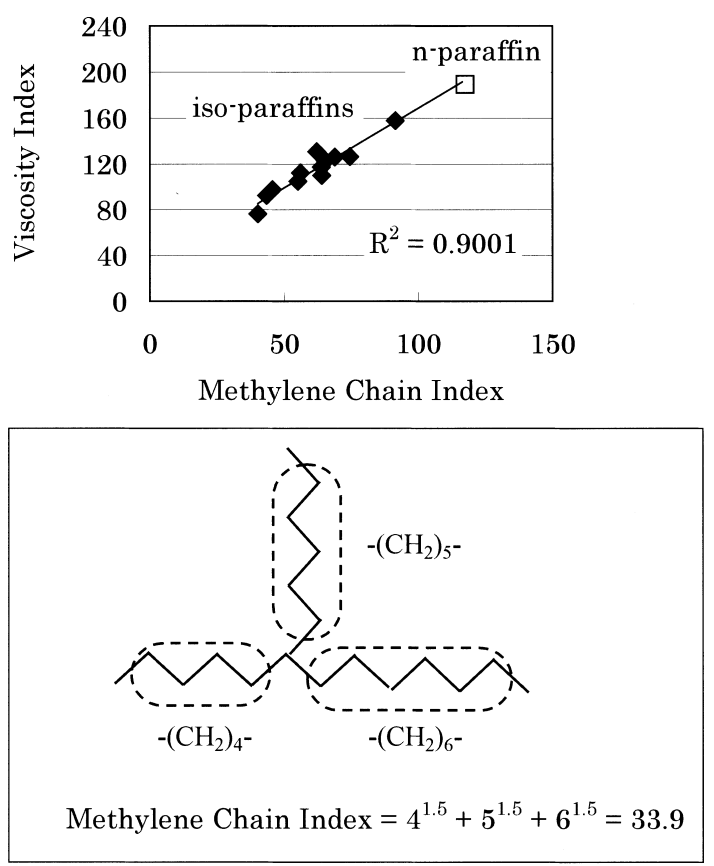

isoparaffin, $\square n$-paraffin.

Fig. 10 Correlation between Methylene Chain Length Index and Viscosity Index of C26

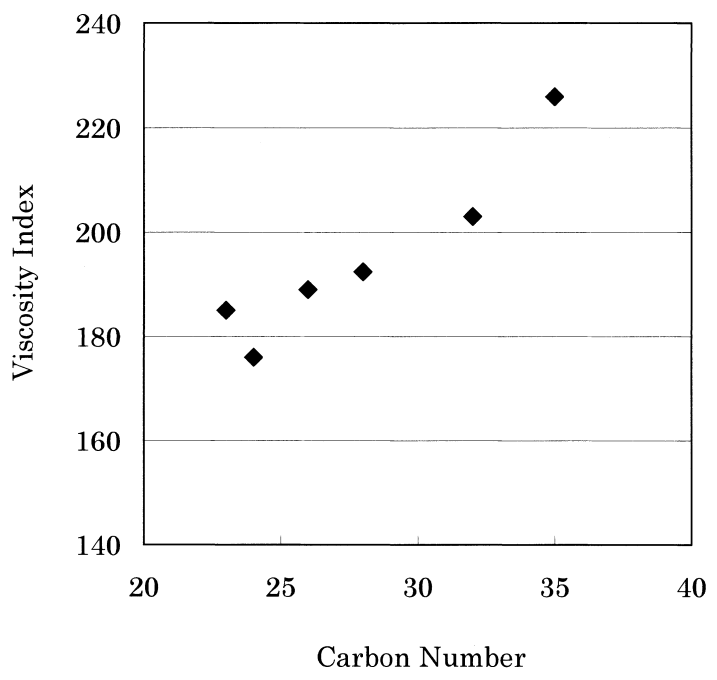

Fig. 11 Dependence of Viscosity Index of $n$-Paraffin on Carbon Number

information explains the utility of Eqs. (7) and (8).

Matsuyama et al. proposed that the area of certain peaks of ${ }^{13} \mathrm{C}$-NMR spectra relate to the methylene chain length of lube oil molecules prepared from crude oil and had good correlations with viscosity inde ${ }^{6}$. The same method was applied to the lube base oils of the present study and the correlation with viscosity index was evaluated. As shown in Fig. 12, the correlation between the proposed index and viscosity index strongly

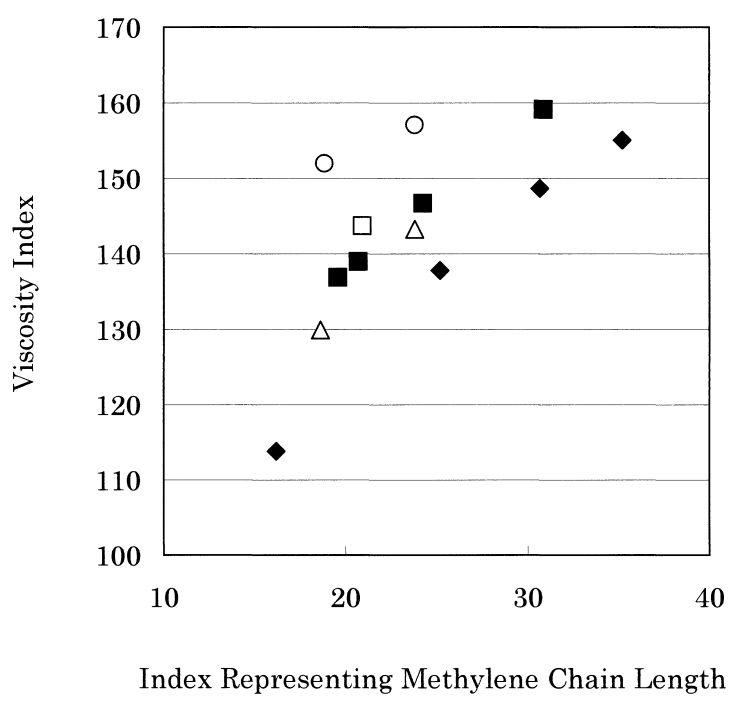

FTW-1, $\square$ FTW-2, $\square$ FTW-2 (400 C cut), $\triangle$ AO-1, $\bigcirc$ AO-2.

Fig. 12 Dependence of Viscosity Index on Methylene Chain Length

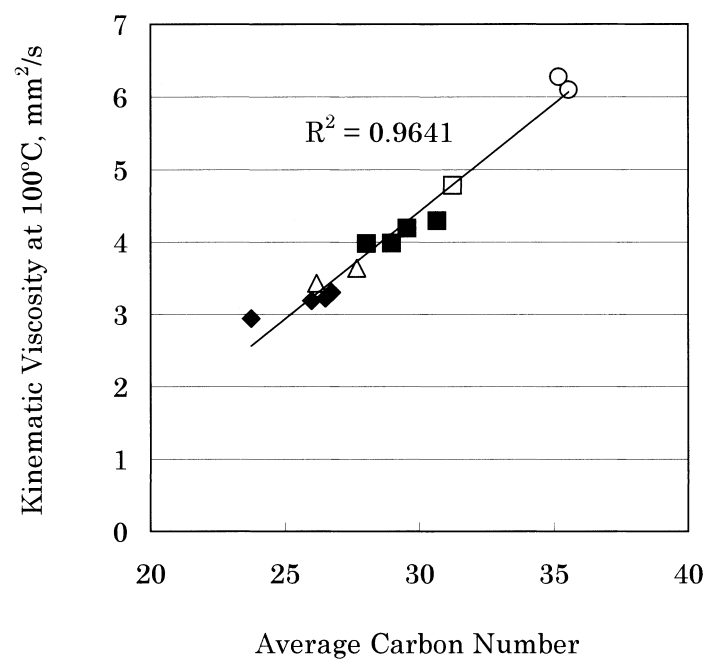

FTW-1, $\square$ FTW-2, $\square$ FTW-2 (400 C cut), $\triangle$ AO-1, $\bigcirc$ AO-2.

Fig. 13 Correlation between Average Carbon Number and Kinematic Viscosity at $100^{\circ} \mathrm{C}$

depended on the feedstock. This result strongly indicates that the size of the molecule is an important factor for viscosity index as well as methylene length and must be included in the structural parameters that represent viscosity index.

\section{4. Kinematic Viscosity and Molecular Structure}

Figures $\mathbf{1 3}$ and $\mathbf{1 4}$ show the correlation between $\mathrm{ACN}$ and kinematic viscosity at $100^{\circ} \mathrm{C}$ and $40^{\circ} \mathrm{C}$, respectively. Kinematic viscosity at $100^{\circ} \mathrm{C}$ had a good correlation with ACNs regardless of feedstock, but the correlation at $40^{\circ} \mathrm{C}$ seemed to be influenced by 


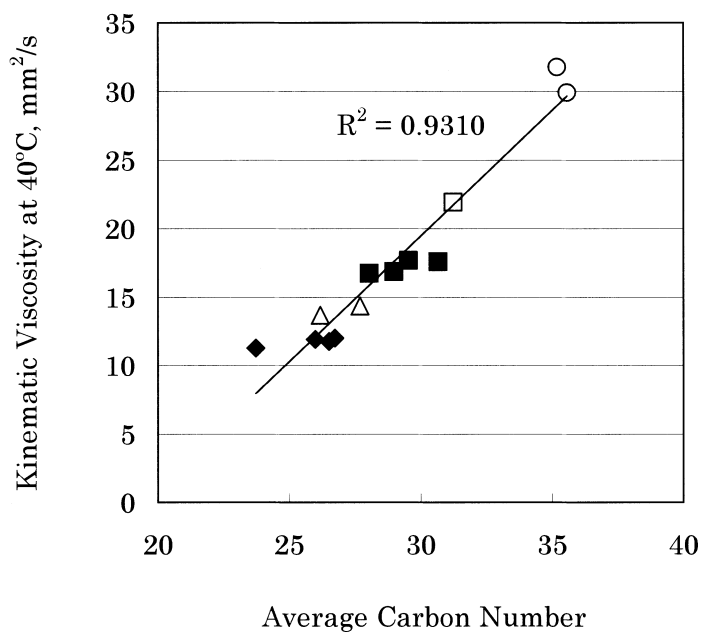

FTW-1, $\square$ FTW-2, $\square$ FTW-2 (400 C cut), $\triangle$ AO-1, $\bigcirc$ AO-2.

Fig. 14 Correlation between Average Carbon Number and Kinematic Viscosity at $40^{\circ} \mathrm{C}$

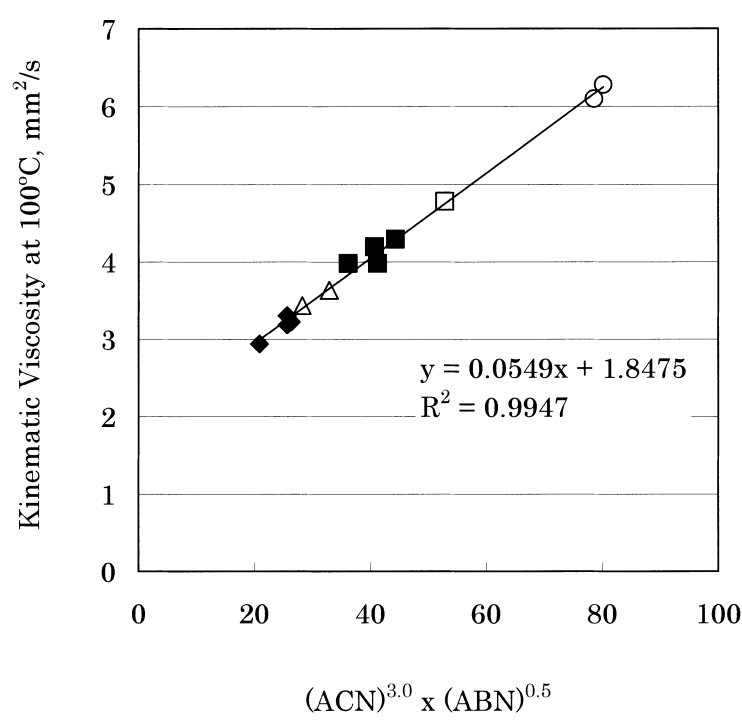

$(\mathrm{ACN})=$ average carbon number, $(\mathrm{ABN})=$ average branching

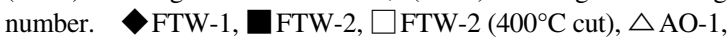
OAO-2.

Fig. 15 Correlation between Structural Parameter $(\mathrm{ACN})^{3.0} \times$ $(\mathrm{ABN})^{0.5}$ and Kinematic Viscosity at $100^{\circ} \mathrm{C}$ of Base Oil

feedstock.

Therefore, a similar formula, $(\mathrm{ACN})^{a} \times(\mathrm{ABN})^{b}$ was applied to kinematic viscosities at both $40^{\circ} \mathrm{C}$ and $100^{\circ} \mathrm{C}$. By employing $(a, b)=(3.5,0.9)$ for the viscosity at $40^{\circ} \mathrm{C}$ and $(3.0,0.5)$ for the viscosity at $100^{\circ} \mathrm{C}$, good linear relationships between viscosity and molecular structural parameter $(\mathrm{ACN})^{a} \times(\mathrm{ABN})^{b}$ were obtained as shown in Figs. 15 and $\mathbf{1 6 .}$

These results indicate that though molecular size is the dominant factor for kinematic viscosity, branching

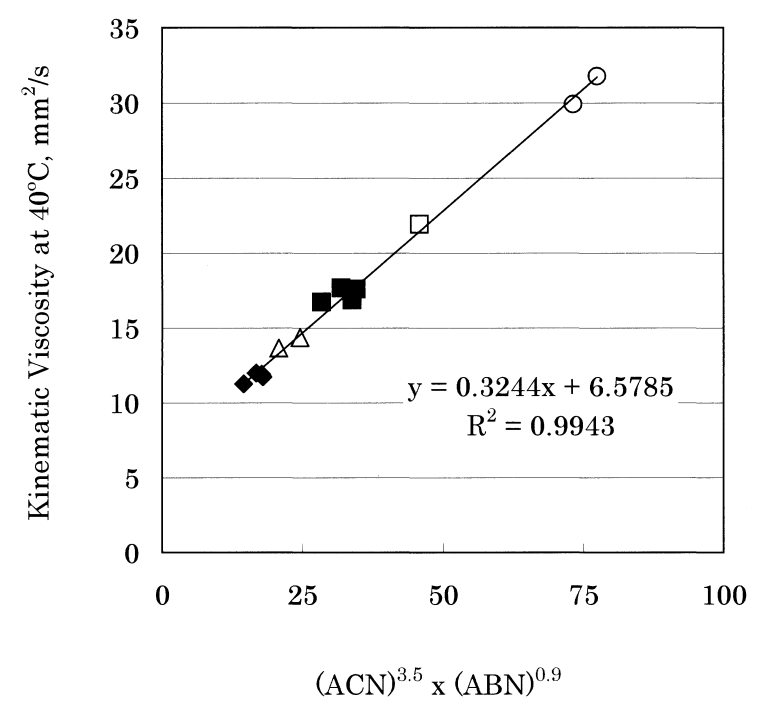

$(\mathrm{ACN})=$ average carbon number, $(\mathrm{ABN})=$ average branching number. FTW-1, $\square$ FTW-2, $\square$ FTW-2 (400 ${ }^{\circ} \mathrm{C}$ cut $), \triangle \mathrm{AO}-1$, AO-2.

Fig. 16 Correlation between Structural Parameter $(\mathrm{ACN})^{3.5} \times$ $(\mathrm{ABN})^{0.9}$ and Kinematic Viscosity at $40^{\circ} \mathrm{C}$ of Base Oil

state is also influential.

\section{Conclusion}

Lube base oils were prepared by hydrocracking/isomerization of Fischer-Tropsch synthesized waxes and long-chain $\alpha$-olefins with various carbon chain lengths. Correlations between operation conditions, viscosity properties of base oil, and molecular structures were investigated.

(a) Viscosity indexes of prepared base oils widely varied from 114 up to 159 with severity of hydrocracking/ isomerization reaction and feedstock used.

(b) Viscosity index decreased steeply with increased severity of hydrocracking/isomerization reaction with all feedstocks. The relationship between conversion and viscosity index depends on the feedstock.

(c) Average branching numbers $(\mathrm{ABN})$ in one molecule were calculated from ${ }^{13} \mathrm{C}$-NMR analysis and average carbon numbers $(\mathrm{ACN})$. $\mathrm{ABN}$ increased and average carbon number (ACN) decreased with increased severity of hydrocracking/isomerization reaction with all feedstocks.

(d) ABN and ACN were applied to the description of viscosity properties of lube oils. The molecular structural parameter $(\mathrm{ACN})^{2} \times(\mathrm{ABN})^{-1}$ showed good correlation with viscosity index. The correlation can be determined only with $\mathrm{ABN}$ and $\mathrm{ACN}$ and is independent of feedstock or operation conditions of the hydrocracking/isomerization reaction.

(e) The relationship between structural parameters and kinematic viscosities can be expressed by $(\mathrm{ACN})^{a} \times$ 
$(\mathrm{ABN})^{b}$ adopting suitable multipliers $a$ and $b$.

\section{References}

1) Gelder, A., Fourth ICIS-LOR World Base Oil Conference, London, 2000.

2) Igarashi, J., Tribologist, 48, (4), 265 (2003).
3) Ondrey, G., Chem. Eng., 111, (5), 23 (2004).

4) Skrebowski, C., Petroleum Review, 691, (58), 18 (2004).

5) Properties of Hydrocarbons of High Molecular Weight, API Research Project 42 Report, 1967.

6) Matsuyama, Y., Yagishita, K., Yoshida, T., 47th R\&D Symposium of Jpn. Petrol. Inst., Tokyo, May 1998, Abstr., p. 49-50.

要旨

\section{Fischer-Tropschワックスの分解・異性化により製造した潤滑油基油の粘度特性と分子構造}

小林 学, 斉藤 政行, 石田 勝昭, 谷地 弘志

(株)ジャパンエナジー 精製技術センター, 335-8502 埼玉県戸田市新曽南3-17-35

炭素数分布の異なる数種のフィッシャー・トロプシュ合成 ワックス，および長鎖の $\alpha$-オレフィンを水素化分解・異性化 することにより潤滑油基油を調製し，反応条件，基油の粘度特 性，そして潤滑油基油の平均分子構造の間の関係について検討 した。

調製された潤滑油基油の粘度指数は，最も高いもので 159 と 非常に高い值を示す一方で，反応条件や用いた原料により大き く異なった。調製された基油の粘度指数は分解・異性化反応の シビアリティー, すなわち分解率と良く相関し, 分解率が低い ほど高い粘度指数を示した。得られた基油が主として非環状パ ラフィンから構成されることから, 基油の「平均炭素数」と ${ }^{13} \mathrm{C}-\mathrm{NMR}$ 分析から決定される $\mathrm{CH}_{3}$ 炭素または $\mathrm{CH}$ 炭素の比率よ り「平均分岐数」を導出した。いずれの原料油を用いた場合で も，分解率の上昇とともに基油の軽質化抒よび分岐の生成が進 行する状況が定量的に観察された。分解率が $10 \%$ 以下でも 2
分岐／分子程度の分岐が生成しており，またそれ以上の分岐の 生成速度は低いことがわかった。

また, 平均炭素数, 平均分岐数は, 動粘度, 粘度指数といっ た基油性状とも良い相関を示し, 粘度指数は, 平均炭素数が大 きいほど，また平均分岐数が小さいほど高い值を示した。

「粘度指数と平均炭素数」,「粘度指数と平均分岐数」の関係 は用いた原料により異なるものであったが，(平均炭素数) $2 \times$ (平均分岐数 $)^{-1}$ 式をパラフィンの構造パラメーターとして用い ることにより, 粘度指数との関係を原料油によらず統一的に扱 うことができた。

同様の構造パラメーター, (平均炭素数) ${ }^{a} \times(\text { 平均分岐数 })^{b}$ 式 を動粘度にも適用した結果, $40^{\circ} \mathrm{C}$ および $100^{\circ} \mathrm{C}$ の動粘度は, それぞれ $(a, b)=(3.5,0.9),(3.0,0.5)$ の時に構造パラメー ターと良い相関を示すことがわかった。 